\title{
Seniorzy na rynku usług bankowych w Polsce
}

\section{SENIORS ON THE MARKET OF BANKING SERVICES IN POLAND}

Cel - Określenie preferencji przedstawicieli Polaków zaliczanych do grupy wiekowej 65+ w korzystaniu z podstawowych rodzajów produktów na rynku bankowym.

Metoda badań - Badania ankietowe przeprowadzone na grupie 569 respondentów zaliczanych do generacji 65+; wykonane przy pomocy kwestionariusza ankietowego w okresie od marca do maja 2018 r. Poprzedzone badaniem pilotażowym zrealizowanym w styczniu $2018 \mathrm{r}$.

Wynik - Określono zachowania Polaków zaliczanych do generacji 65+ na rynku ustug bankowych. Oszacowano poziom zainteresowania produktami bankowymi i poziom aktywności $w$ korzystania tych produktów oraz ustalono preferowane sposoby realizacji ustug bankowych. Dokonano analiza portfela produktów bankowych tego segmentu klientów.

Oryginalność/Wartość - Wyniki badań stanowia poszerzenie stanu wiedzy na temat zachowań klientów zaliczanych do generacji 65+ na polskim rynku ustug bankowych.

Słowa kluczowe: usługi bankowe, ubankowienie, pokolenie $65+$

Kody JEL: G21, J14.

\section{Wprowadzenie}

Funkcjonowanie jednostki we współczesnym świecie jest bezpośrednio związane z korzystaniem przynajmniej w ograniczonym zakresie z produktów bankowych. Brak możliwości korzystania z podstawowych produktów bankowych a w szczególności brak możliwości posiadania rachunku bankowego uważany jest za formę wykluczenia finansowego jednostki ${ }^{1}$, która w znacznym stopniu wpływa na komfort jej życia.

\footnotetext{
${ }^{1}$ L. Anderloni: Access to Bank Account and Payment Services. [w:] L. Anderloni, M.D. Braga, E.M. Carluccio (red.), New Frontiers in Banking Services. Emerging Needs and Tailored Products for Untapped Markets. Springer Verlag, Berlin-Heidelberg 2007; Financial Services Provision and Prevention of Financial Exclusion, EC Report VC/2006/0183, European Commission. Brussels 2008; L. Richardson, J. Le Grand: Outsider and insider expertive: The Response of Residents of Deprived Neighbourhoods to an Academic Definition of Social Exlusion. CASE Papers 57, London School of Economics, Centre for Analysis of Social Exlusion 2002; S. Sinclair: Financial Exclusion: An Introductory Survey. Centre for Research into Socially Inclusive Services (CRSIS). Edinburgh College of Art/Heriot Watt University Edinburgh 2001; C. Connolly, Hajjaj, K.: Financial Services and Social Exclusion. Financial Services Consumer Policy Centre. University of New South Wales Sydney 2001.

Po raz pierwszy wykluczenie finansowe jako procesy służące ograniczeniu dostępu do systemu finansowego określonym grupom społecznych zostało zdefiniowane przez A. Leyshon i N. Thrift. Zobacz A. Leyshon, N. Thrift, Geographies of financial exclusion: financial abandonment in Britain and United States, Transactions of the Institute of British Geographers, "New Series", 20/1995
} 
Stanowiło to jedną z podstawowych determinant, która miała wpływ na fakt, że na przełomie XX i XXI wieku odnotowano na świecie dynamiczny wzrost poziomu ubankowienia, który z 50,6\% w 2011 r. wzrósł do 62\% w 2014 r. oraz do 68,5\% w 2017 r. $^{2}$. Również w Polsce zostało odnotowane to zjawisko. Potwierdzają je przeprowadzone badania nt. „Postawy Polaków wobec obrotu bezgotówkowego”, które wykazały wzrost poziomu ubankowienia z $78 \%$ w 2009 r. do $83 \%$ w 2016 r. ${ }^{3}$. Natomiast zdaniem analityków Banku Światowego poziom ten wzrósł z 70,2\% w 2011 r. do 77,9\% w 2014 r.. Aby ostatecznie w 2017 r. osiągnąć wartość 86,7\% ${ }^{4}$.

Poziom ubankowienia $\mathrm{w}$ bezpośredni sposób jest związany z liczbą rachunków bankowych posiadanych przez mieszkańców danego państwa. Na podstawie „Raportów o rynku kont osobistych" można stwierdzić, że w latach 2010 - 2018 liczba kont osobistych mieszkańców Polski (rys. 1) wzrosła z 23,276 mln do 32,894 mln czyli o 41,32\%. Natomiast zgodnie z danymi NBP liczba rachunków bieżących w złotych osób prywatnych wzrosła z 44,074 mln w 2010 r. do 65,179 mln w 2017 r. czyli o 47,88\% ${ }^{5}$.
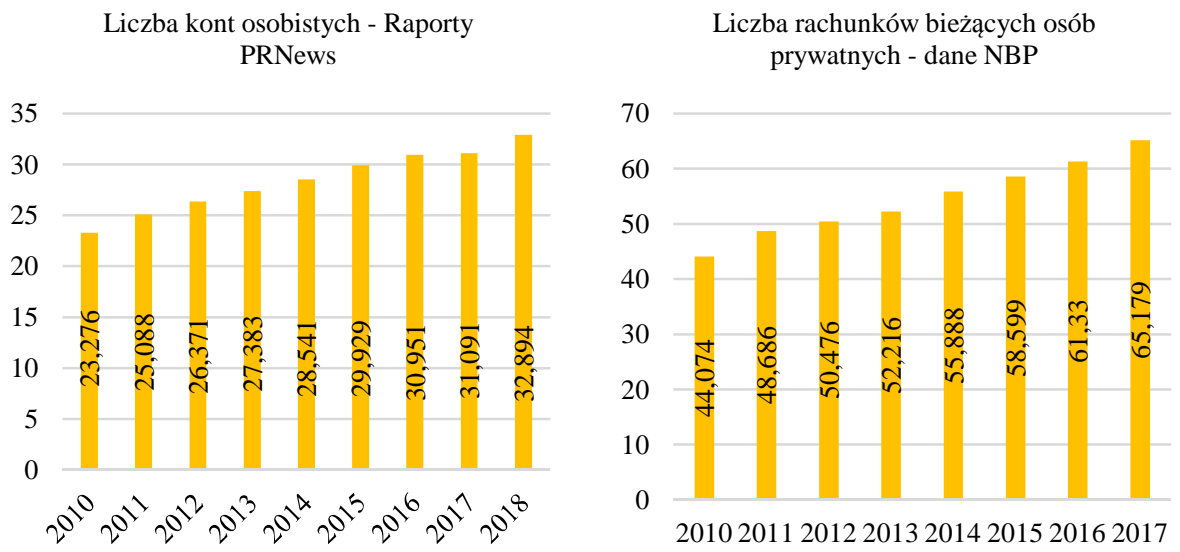

Rysunek 1. Liczba rachunków osobistych (ROR) ${ }^{6}$ w Polsce w latach 2010 - 2018 oraz liczba rachunków bieżących w złotych osób prywatnych ${ }^{7}$ w latach 2010 - 2017 w milionach sztuk.

Źródło: opracowanie na podstawie Raportów prnews-pl-rynek-kont-osobistych oraz Porównanie wybranych elementów polskiego systemu płatniczego z systemami innych krajów Unii Europejskiej za 2017 r. Narodowy Bank Polski, Warszawa 2018.

\footnotetext{
2 The Little Data Book on Financial Inclusion. International Bank for Reconstruction and Development / The World Bank, Washington 2018, s. 2

Średni poziom ubankowienia mieszkańców Europy i Azji Środkowej jest nieco niższy i wynosił $65,3 \%$. Natomiast średni poziom ubankowienia w Polsce wynosił $86,7 \%$.

${ }^{3}$ D. Maison: Postawy Polaków wobec obrotu bezgotówkowego. 2017. http://www.nbp.pl/ home.aspx?f=/systemplatniczy/obrot_bezgotowkowy/obrot_bezgotowkowy.html (data wejścia: 20.02.2019)

${ }^{4}$ The Little Data Book...op.cit., s. 125.

5 Porównanie wybranych elementów polskiego systemu płatniczego z systemami innych krajów Unii Europejskiej za 2017 r.. Narodowy Bank Polski Warszawa 2018.

6 W Raportach PRNews podana jest uzyskana od banków informacja na temat liczby rachunków oszczędnościowo-rozliczeniowej.

${ }^{7}$ NBP do rachunków bieżących zalicza zgodnie z metodologią Europejskiego Banku Centralnego: rachunki służące do dokonywania rozliczeń i płatności, bezterminowe rachunki oszczędnościowe z możliwością wypłaty środków na żądanie bez utraty odsetek lub poniesienia istotnych kosztów, rachunki walutowe, rachunki maklerskie i rachunki techniczne. Zobacz: Porównanie wybranych elementów polskiego systemu płatniczego...op.cit., s. 7.
} 
Wraz ze wzrostem liczby rachunków bankowych systematycznej zmianie ulegała również liczba rachunków bankowych przypadająca na jednego mieszkańca. Na początku XXI wieku w $2001 \mathrm{r}$. wynosiła ona tylko 0,4 rachunku, w 2005 r. wzrosła do 0,9 rachunku, w 2010 r. do 1,3 rachunku a w 2015 r. do 1,7 rachunku. W 2017 r. wynosiła już 1,9 rachunku i była wyższa niż średnia liczba rachunków bankowych na jednego mieszkańca w UE $(1,7)$ i w Strefie Euro $(1,7)^{8}$.

Większość banków swoją ofertę dostosowuje do potrzeb przyszłościowych grup klientów, którzy będą korzystać z ich usług przez wiele dziesięcioleci. Stara się pozyskać jak najmłodszych klientów i szybko zbudować z nimi więzi lojalnościowe. Nie kiedy zapominając $w$ swoich działaniach o grupie klientów w wieku poprodukcyjnym, którzy również oczekują indywidualnego podejścia do ich obsługi i nie są wstanie w pełni dostosować się do nowoczesnych form obsługi. O osobach, których większość życia przypadła w innym systemie ekonomicznym, które dopiero w wieku dojrzałym dołączyły do grona klientów banków. Preferujących aktualnie w większości tradycyjne formy realizacji usług bankowych oraz płatności gotówkowe. Nie uwzględniają więc faktu, że na świecie coraz większą wagę przykłada się do tzw. srebrnej ekonomii .

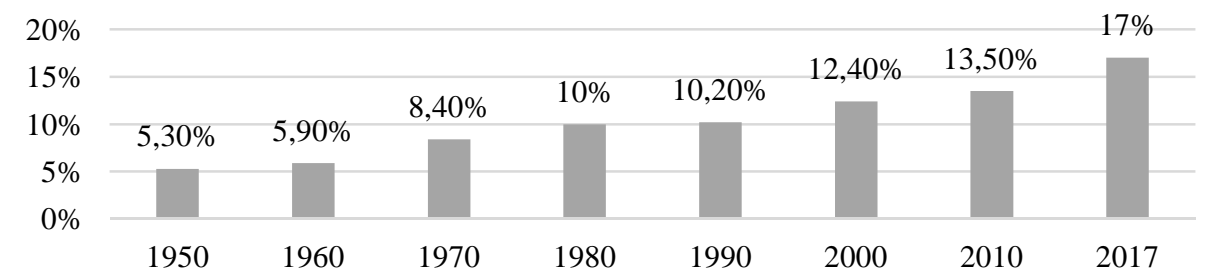

Rysunek 2. Odsetek mieszkańców Polski, którzy ukończyli 65 lat.

Źródło: opracowanie na podstawie Rocznik demograficzny. Główny Urząd Statystyczny, Warszawa 2018, s. 46 i 48.

Aktualnie w Polsce mamy do czynienia $\mathrm{z}$ systematycznym starzeniem się społeczeństwa. Jak przedstawiono na rysunku 2 w 1950 r. liczba mieszkańców, którzy ukończyli 65 lat wynosiła tylko 5,3\%, w 1990 r. w momencie zmiany systemu gospodarczego wzrosła do $10,2 \%$ a na koniec 2017 r. stanowiła aż 17\%. Takie zmiany demograficzne spowodowały, że w 2017 r. liczba potencjalnych klientów polskich banków, którzy ukończyli 65 lat wynosiła 6,52 mln osób. W grupie tej znajdowało się

\footnotetext{
${ }^{8}$ Ibidem, s. 8.

9 "Srebrna ekonomia” obejmuje istniejące i powstające możliwości gospodarcze związane z rosnącymi wydatkami publicznymi i konsumenckimi związanymi ze starzeniem się populacji i specyficznymi potrzebami ludności powyżej 50 roku życia. Zobacz: Growing the European Silver Economy. Background Paper. European Commission, 2015.

Zdaniem części Autorów pojęcie srebrnej ekonomii należy rozpatrywać jako możliwość wykorzystania starzenia się populacji do takiego ukierunkowania rozwoju, w którym zmiana struktury potrzeb ludności oraz pewien wzrost ich aktywności mogłyby stać się źródłem postępu i wzrostu gospodarczego. Zobacz S. Golinowska, Srebrna gospodarka - ekonomiczny wymiar procesu starzenia się populacji, (w:) Strategie działania w starzejącym się społeczeństwie. Tezy i rekomendacje, Rzecznik Praw Obywatelskich, Warszawa 2012 .
} 
3,949 mln kobiet oraz 2,571 mln mężczyzn ${ }^{10}$. Należy również zaznaczyć, że w najbliższych latach można oczekiwać, że liczba należących do tego segmentu klientów banków jeszcze zwiększy się ${ }^{11}$. Dlatego banki budując swój portfel produktów nie powinny wyłącznie skupiać się na tworzeniu nowych produktów oraz nowoczesnych kanałów ich dystrybucji zaspokajających zgłaszane potrzeby przez przedstawicieli młodego oraz średniego pokolenia klientów. Muszą w nim również uwzględniać specyfikę obsługi seniorów ${ }^{12}$ oraz fakt, że okres ich obsługi systematycznie będzie ulegał wydłużeniu. Obecnie przeciętna liczba lat dalszego trwania życia dla osób w wieku powyżej 65 lat $^{13}$, a tym samym długość okresu przez jaki mogą być klientami banków, wynosi dla kobiet 19,27 lat a dla mężczyzn 14,17 lat ${ }^{14}$.

Banki uwzględniając powyższe informacje nie mogą sobie pozwolić na rezygnacje z dochodów jakie mogą czerpać, przeciętnie przez kilkanaście lat, od przedstawicieli tego wielomilionowego segmentu klientów. Niestety zdecydowana większość banków nie podejmuje działań mających na celu stworzenie oferty specjalnie dedykowanej dla seniorów uważając, że ta grupa klientów może korzystać ze standardowej oferty. Nielicznymi przykładami aktualnie oferowanych takich rachunków mogą być „Konto aktywne 50+" oferowane przez Santander Bank Polska S.A., „Wygodne konto dla Klientów ZUS" oferowane przez część banków spółdzielczych z Grupy BPS oraz „Konto Aktywny Nestor” znajdujące się w ofercie Banku Pocztowego. Należy również podkreślić, że w ostatnim dziesięcioleciu kilka banków wprowadziło do swojej oferty konta dedykowane dla seniorów jednak te oferty nie zawsze były korzystniejsze od standardowej oferty banku i w większości przypadków zostały usunięte z oferty.

\section{Cel i metodyka badań}

Problematyka zachowania się seniorów na rynku produktów finansowych stanowi bardzo ważne zagadnienie $\mathrm{z}$ punktu widzenia funkcjonowania systemu bankowego. Wybrane zagadnienia $\mathrm{z}$ nią związane coraz częściej stanowią jeden z elementów różnych badań związanych z zachowaniem się klientów na tym rynku ${ }^{15}$. Dlatego widoczna jest

\footnotetext{
${ }^{10}$ Rocznik demograficzny. (2018). Główny Urząd Statystyczny, Warszawa 2018, s. 139.

${ }^{11}$ Aktualnie liczba mieszkańców Polski w wieku 60 - 64 lata wynosi 2,773 mln $(1,475$ mln kobiet oraz 1,298 mln mężczyzn). Natomiast liczba mieszkańców w wieku 65 - 69 lat wynosi 2,354 mln (1,303 mln kobiet oraz 1,05 mln mężczyzn) a w wieku ponad 80 lat wynosi 1,642 mln (1,134 mln kobiet oraz 0,507 mln mężczyzn).

${ }^{12}$ Pojęcie osoby starszej jest różnie definiowane. ONZ zalicza do nich osoby $65+$, WHO osoby $60+$.

13 Przeciętna liczba lat dalszego trwania życia dla osób w wieku powyżej 65 lat wynosiła odpowiednio: w 1980 r. - 14,38 lat dla kobiet i 10,18 lat dla mężczyzn, w 1990 r. - 14,96 lat dla kobiet i 10,33 lat dla mężczyzn, w 2000 r. - 16,51 lat dla kobiet i 11,72 lat dla mężczyzn.

${ }^{14}$ Rocznik demograficzny...op. cit., s. 386.

15 Zachowanie się przedstawicieli seniorów na rynku usług finansowych stanowi przedmiot badań zarówno naukowców jak i instytucji które mają stać na straży wolności i równego traktowania obywateli oraz instytucji, których zadaniem jest podejmowanie działań mających na celu podwyższanie w sektorze bankowym standardów obsługi klientów. Jako przykłady takich badań można wskazać m.in. D. Maison: Badanie postaw Polaków powyżej 60. roku życia wobec obrotu bezgotówkowego - raport z badań, NBP, Warszawa 2012; D. Maison: Postawy Polaków wobec obrotu bezgotówkowego. (2017). http://www.nbp.pl/ home.aspx?f=/ systemplatniczy/obrot_bezgotowkowy/obrot_bezgotowkowy.html (data wejścia: 20.02.2019); Raport InfoSenior (2019). Związek Banków Polskich. https://zbp.pl/public/repozytorium/...2019/ZBP InfoSenior_2019_POPR_21.01.pdf (data wejścia: 20.02.2019); B. Świecka: Ocena sytuacji finansowej osób starszych w Polsce ze szczególnym uwzględnieniem zasobności i zadłużenia. Problemy Zarządzania, vol. 14,
} 
potrzeba prowadzenia systematycznie powtarzalnych badań, których głównym celem byłoby określenie zmieniających się preferencji w korzystaniu z usług bankowych przez przedstawicieli pokolenia poprodukcyjnego. Wykorzystanie wiedzy uzyskanej na podstawie takich badań umożliwiłoby instytucjom finansowym dostosowanie oferowanego portfela produktów do oczekiwań klientów. Działania takie miałyby nie tylko wpływ na poziom oczekiwanych zysków tych instytucji ale również na lepsze zaspokojenie potrzeb tej grupy klientów oraz na ograniczenie poziomu wykluczenia finansowego seniorów.

Badania empiryczne dotyczące zachowania się przedstawicieli mieszkańców Polski zaliczanych do pokolenia 65+ na rynku usług bankowych miały charakter badań pierwotnych. Zostały przeprowadzone w formie bezpośredniego badania ankietowego w okresie od marca do maja 2018 r.. Badania te zostały poprzedzone badaniami pilotażowymi, które odbyły się w miesiącu styczniu 2018 r.. Do doboru grupy badawczej, w skład której wchodziło 569 respondentów, została wykorzystana metoda doboru nielosowego. W analizowanej grupie badawczej znajdowało się 313 kobiety (55\%) oraz 256 mężczyzn (45\%) mieszkających na terenie południowo-wschodniej Polski. Uczestnicy badań zostali podzieleni również na pięć grup ze względu na miejsce zamieszkania (wieś - 19,51\% , miasto do 25-tys. mieszkańców - 20,74\%, miasto 25-50tys. mieszkańców - 18,28\%, miasto 50-100-tys. mieszkańców - 21,26\%, miasto ponad 100-tys. mieszkańców - 20,21\%), na pięć grup ze względu na dochód (do 1500 PLN $38,14 \%, 1501-2500$ PLN - 34,97\%, 2501-4000 PLN - 19,51\%, 4001-6000 PLN $5,09 \%$, powyżej 6000 PLN - 2,28\%) oraz na cztery grupy ze względu na wykształcenie (podstawowe $-16,52 \%$, zawodowe $-42,7 \%$, średnie $-31,81 \%$, wyższe $-8,96 \%$ ).

Podstawowym celem przeprowadzonych badań była próba określenia preferencji przedstawicieli mieszkańców Polski zaliczanych do grupy wiekowej 65+ w korzystaniu z podstawowych rodzajów produktów na rynku bankowym.

\section{Aktywność przedstawicieli pokolenia 65+ na rynku usług bankowych}

Ponad $78 \%$ uczestniczących w badaniach przedstawicieli pokolenia $65+$ zadeklarowało, że korzysta z usług bankowych. Otrzymane wyniki pozwalają na stwierdzenie, że zarysowała się wyraźna różnica pomiędzy poziomem aktywności na tym polu wśród kobiet $(72,5 \%)$ i mężczyzn $(84,8 \%)$. Należy również zaznaczyć, że analizując poziom aktywności uczestników badań w tym zakresie ze względu na ich miejsce zamieszkania, wykształcenie oraz osiągany dochód (rys. 3) stwierdzono, że procentowy udział korzystających z usług bankowych rósł wraz ze wzrostem wielkości zamieszkiwanej miejscowości, poziomu ich wykształcenia oraz osiąganego przez nich dochodu.

Należy jednak zaznaczyć, że wysoki odsetek osób deklarujących korzystanie z usług bankowych nie przekłada się na częstotliwość korzystania z nich. Przedstawiciele pokolenia $65+\mathrm{w}$ korzystaniu $\mathrm{z}$ usług bankowych charakteryzowali się bardzo małą aktywnością (tabela 1). Ponad 54\% respondentów zadeklarowało, że korzysta $\mathrm{z}$ nich raz $\mathrm{w}$ miesiącu ${ }^{16}$ a $22,7 \%$ ankietowanych stwierdziło, że korzysta z nich jeszcze rzadziej.

nr 2 (59)/2016; Osoby starsze na rynku usług finansowych - analiza i zalecenia. Biuletyn Rzecznika Praw Obywatelskich 2013, nr 4.

${ }^{16}$ Raz w miesiącu z usług bankowych częściej korzystały kobiety $(55,5 \%)$ niż mężczyźni $(52,5 \%)$. Wśród kobiet $\mathrm{z}$ taką częstotliwością $\mathrm{z}$ tych usług najczęściej korzystały respondentki mieszkające w miastach powyżej 
Wśród respondentów, którzy stwierdzili, że korzystają z usług bankowych rzadziej niż raz w miesiącu największą grupę stanowili mieszkańcy wsi $(42,1 \%)$, ankietowani legitymujący się wykształceniem podstawowym $(31,8 \%)^{17}$ oraz dochodem do 1500 PLN $(34,7 \%)$. Ankietowani ci należeli więc do tych segmentów społeczeństwa, które w największym stopniu narażone są ma możliwość wystąpienia zjawiska wykluczenia finansowego. Należy również podkreślić, że duży wpływ na taką częstotliwość korzystania z usług bankowych przez respondentów może mieć również fakt, że co trzeci uczestnik badań zadeklarował, że otrzymywaną emeryturę wypłaca jednorazowo w całości $\mathrm{z}$ banku ${ }^{18}$.
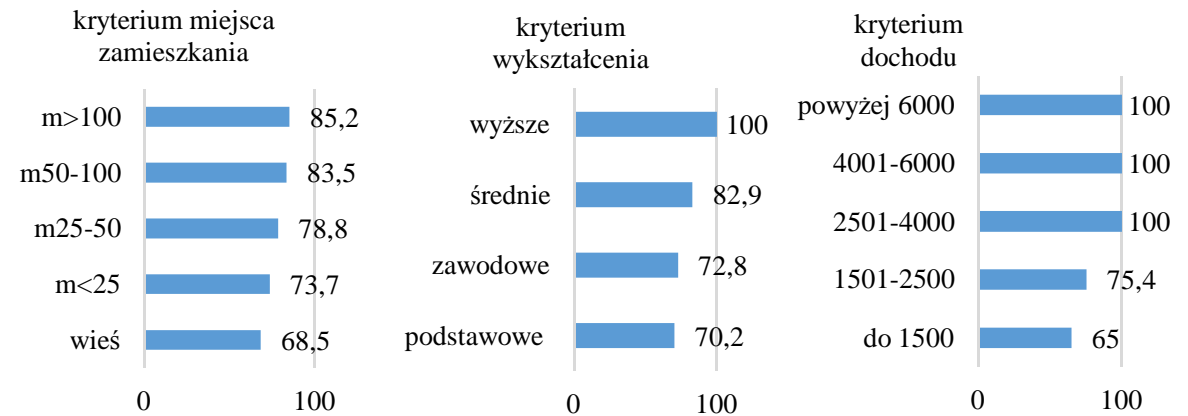

Rysunek 3. Odsetek respondentów korzystający z usług bankowych.

Oznaczenia na rysunkach $3,4-\mathrm{m}<25$ - mieszkańcy miast poniżej 25-tys. mieszkańców, m25-50 mieszkańcy miast od 25 do 50 tys. mieszkańców, m50-100 - mieszkańcy miast od 50 do 100 tys. mieszkańców, m>100 - mieszkańcy miast ponad 100 tys. mieszkańców.

Źródło: opracowanie na podstawie badań własnych.

Tylko 23,2\% uczestników badań było aktywnymi uczestnikami rynku usług bankowych korzystając $\mathrm{z}$ nich kilka razy w miesiącu. Zachowania takie najczęściej deklarowali mieszkańcy miast 50-100-tysięcy mieszkańców ${ }^{19}$ (26,7\%), ankietowani legitymujący się wyższym wykształceniem $(37,2 \%)$ oraz dochodami w przedziale od 4001 do $6000 \mathrm{PLN}^{20}(58,6 \%)$. Analiza otrzymanych wyników pozwala stwierdzić, że wzrost poziomu aktywności w korzystaniu $\mathrm{z}$ usług bankowych (dla ogółu respondentów) był związany ze wzrostem posiadanego dochodu. A w przypadku segmentu uczestniczących w badaniach mężczyzn również ze wzrostem poziomu ich wykształcenia.

100-tysięcy mieszkańców (70\%), ankietowane legitymujące się średnim wykształceniem (68,9\%) oraz badane o dochodach w przedziale od 2501 do 4000 (61,2\%). Z kolei wśród mężczyzn mieszkańcy miast powyżej 100tysięcy mieszkańców $(56,2 \%)$, respondenci posiadający wykształcenie zawodowe $(63,7 \%)$ oraz badani o dochodach w przedziale od 2501 do 4000 (61,3\%).

${ }^{17} \mathrm{Na}$ drugim miejscu znaleźli się ankietowani z wyższym wykształceniem $(27,4 \%)$. Należy zaznaczyć również, że w segmencie mężczyzn największą grupe respondentów korzystających $\mathrm{z}$ usług bankowych rzadziej niż raz w miesiącu stanowi właśnie respondenci legitymujący się wyższym wykształceniem $(31,8 \%)$.

${ }^{18}$ Wypłacanie emerytury jednorazowo w całości z banku zadeklarowało 32\% kobiet oraz 37,1\% mężczyzn.

${ }^{19} \mathrm{Na}$ zaznaczenie zasługuje fakt, że największą aktywnością na tym polu wykazywały się kobiety mieszkające w miastach 25-50-tysięczne (26,2\%) oraz mężczyźni zamieszkujący miasta 50-100-tysięczne (31,2\%).

${ }^{20}$ Trzeba zaznaczyć, że aktywność osób osiągających najwyższe dochody (ponad 6000 PLN) była niższa i wynosiła $46,1 \%$. 
Analizując preferowany przez przedstawicieli pokolenia $65+$ sposób realizacji usług bankowych (tabela 1) stwierdzamy, że zdecydowana większość respondentów opowiada się za tradycyjnym bezpośrednim kontaktem z pracownikiem banku (90,3\%). Należy zaznaczyć, że taka forma kontaktu częściej była wskazywana przez mężczyzn ${ }^{21}(93,1 \%)$ niż przez kobiety ${ }^{22}(87,7 \%)$. Mężczyźni przykładali również większą wagę aby być obsługiwanym przez tego samego pracownika banku. Na taką formę realizacji usług bankowych najczęściej wskazywali mężczyźni będący mieszkańcami miast do 25tysięcy mieszkańców $(47,7 \%)$, respondenci posiadający wyższe wykształcenie $(68,2 \%)$, ankietowani o dochodach w przedziale od 4001 do 6000 PLN $(72,2 \%)$. Z kolei w grupie ankietowanych kobiet z takiej formy obsługi chciała korzystać co czwarta respondentka. Najbardziej zainteresowane były nią mieszkanki wsi $(35,9 \%)$, respondentki legitymujące się wykształceniem podstawowym $(70,8 \%)^{23}$ oraz ankietowane posiadające dochody w przedziale od 4001 do 6000 PLN (54,5\%). Interesującym jest również fakt, że wśród respondentów odsetek zainteresowanych taką formą realizacji usług bankowych rósł wraz ze zmniejszaniem się zamieszkiwanej przez nich miejscowości.

Tabela 1. Częstotliwość i preferowany sposób korzystania z usług bankowych przez respondentów (w \%)

\begin{tabular}{|l|c|c|c|}
\hline \multicolumn{4}{|c|}{ Częstotliwość korzystania z usług bankowych } \\
\hline & Ogółem & Kobiety & Mężczyźni \\
\hline kilka razy w miesiącu & 23,20 & 20,26 & 26,27 \\
\hline raz w miesiącu & 54,05 & 55,51 & 52,53 \\
\hline raz na dwa miesiące & 11,71 & 12,78 & 10,60 \\
\hline raz na kwartał & 6,31 & 6,17 & 6,45 \\
\hline rzadziej niż raz na kwartał & 4,73 & 5,29 & 4,15 \\
\hline \multicolumn{2}{|c|}{ Preferowany sposób realizacji usług bankowych } \\
\hline $\begin{array}{l}\text { bezpośredni z dowolnym } \\
\text { pracownikiem banku }\end{array}$ & Ogółem & Kobiety & Mężczyźni \\
\hline $\begin{array}{l}\text { bezpośredni z tym samym } \\
\text { pracownikiem banku }\end{array}$ & 56,76 & 60,35 & 53 \\
\hline telefoniczny & 33,56 & 27,31 & 40,09 \\
\hline internetowy & 8,33 & 10,13 & 6,45 \\
\hline
\end{tabular}

Źródło: opracowanie na podstawie badań własnych.

Tylko co dziesiąty uczestnik badań zadeklarował, że preferuje inny sposób korzystania z usług bankowych tj.: telefoniczny $(8,3 \%)$ lub internetowy $(1,35 \%)$. $\mathrm{Z}$ realizacji usług bankowych przez telefon częściej korzystały kobiety $(10,1 \%)$ niż mężczyźni $(6,45 \%)$. Największy odsetek kobiet korzystających z tego kanału dystrybucji usług bankowych znajdował się wśród mieszkanek miast powyżej 100-tysięcy

21 Największy odsetek mężczyzn, którzy preferowali korzystanie z usług bankowych bezpośrednio w placówkach bankowych znajdował się wśród mieszkańców miast 50-100-tysięcy mieszkańców (95,8\%), respondentów legitymujących się podstawowym wykształceniem $(97,6 \%)$ oraz wśród ankietowanych o dochodach do 1500 PLN (96,3\%).

${ }^{22}$ Największy odsetek kobiet, które preferowały korzystanie z usług bankowych bezpośrednio w placówkach bankowych znajdował się wśród mieszkanek wsi (92,3\%), respondentek ze średnim wykształceniem $(92,9 \%)$ oraz wśród ankietowanych o dochodach do 1500 PLN (94,2\%).

23 Największe zainteresowanie bezpośrednim kontaktem z tym samym pracownikiem banku zarówno w segmencie uczestniczących w badaniach kobiet jak i mężczyzn występowało wśród osób z wykształceniem podstawowym i wyższym. 
mieszkańców (14\%), respondentek z wyższym wykształceniem (13,8\%), ankietowanych, których dochody przekraczały 6000 PLN (50\%). Natomiast w segmencie ankietowanych mężczyzn największy poziom zainteresowania taką formą realizacji usług bankowych występował wśród mieszkańców miast 25-50-tysięcy (10\%), badanych legitymujących się wyższym wykształceniem $(13,6 \%)$, respondentów posiadających dochody wyższe niż 6000 PLN $(11,1 \%)$.

Nowoczesny kanał realizacji usług bankowych jakim jest Internet, w analizowanej grupie badawczej, preferowany był tylko przez $1,35 \%$ respondentów. Większe zainteresowanie taką formą było wśród kobiet (2,2\%) niż wśród mężczyzn $(0,46 \%)$. Należy zaznaczyć, że przez Internet usługi realizowali wyłącznie mieszkańcy dużych miast: 50-100-tysięcy mieszkańców $(1,98 \%)$ oraz ponad 100-tysięcy mieszkańców $(4,08 \%)$, respondenci posiadający wyższe wykształcenie $(11,8 \%)$, ankietowani o dochodach w przedziałach: 2501-4000 (3,45\%) i 4001-6000 (3,45\%). Niski poziom zainteresowania wśród respondentów korzystaniem $\mathrm{z}$ nowoczesnych kanałów dystrybucji usług bankowych może w dużym stopniu wynikać z braku dostępu do nich lub braku umiejętności posługiwania się nimi ${ }^{24}$. Należy jednak zakładać, że w kolejnych latach będzie następował wzrost zainteresowania tymi formami realizacji usług bankowych wynikający z dołączania do grupy seniorów kolejnych roczników, których przedstawiciele w większym stopniu w okresie swojej aktywności zawodowej korzystali nowoczesnych form komunikacji i realizacji operacji finansowych.

\section{Portfel produktów bankowych seniorów}

Do analizy portfela produktów bankowych z jakich korzystają przedstawiciele pokolenia $65+$ wykorzystano rachunek bankowy, produkty depozytowe i kredytowe oraz karty bankowe.

\section{Rachunek bankowy}

W analizowanej grupie badawczej występowało wysokie ubankowienie, które zgodnie $\mathrm{z}$ deklaracjami respondentów kształtowało się na poziomie $84,9 \%{ }^{25}$. Wartość ta była

\footnotetext{
${ }^{24} \mathrm{~W}$ badaniach dotyczących „Postrzegania zjawiska wykluczenia finansowego przez Polaków” ponad 95\% ankietowanych w wieku powyżej 65 lat zadeklarowało, że nigdy samodzielnie nie zrealizowało przelewu internetowego a $100 \%$ respondentów powyżej 65 lat stwierdziło, że nie ma możliwości realizowania płatności przy pomocy telefonu komórkowego. Zobacz: M. Sołtysiak: Zjawisko wykluczenia finansowego w opiniach przedstawicieli pokolenia baby boombers. Zeszyty Naukowe Wydziału Nauk Ekonomicznych Politechniki Koszalińskiej nr 21/2017, s. 232.

${ }^{25}$ Zadeklarowany przez respondentów poziom ubankowienia był znacznie wyższy od poziomu ubankowienia uczestników badań nt. „Postawy Polaków wobec obrotu bezgotówkowego”. W kolejnych edycjach tych badań odsetek osób w wieku 65+ posiadających rachunek bankowy wynosił odpowiednio: dla grupy badawczej w 2009 r. - 53\%, dla grupy badawczej w 2013 r. - 77\% i dla grupy badawczej w 2016 r. - 61\%. Zobacz D. Maison: Postawy...op.cit., s. 21.

Natomiast w przeprowadzonych w 2012 r. badaniach nt. „Postaw Polaków powyżej 60. roku życia wobec obrotu bezgotówkowego" w grupie wiekowej 65 - 74 lat odsetek posiadających rachunek bankowy wynosił $57 \%$ a w grupie wiekowej ponad 75 lat tylko 37\%. Zobacz D. Maison: Badanie postaw...op.cit., s. 22.

Z kolei Raport InfoSenior informuje, że rachunek bankowy posiada $57 \%$ osób powyżej 59 roku życia (Raport InfoSenior 2018, s. 14). Zaś w badania przeprowadzone w grudniu 2018 r. na zlecenie Związku Banku Polskich wykazały, że najpopularniejszym wśród emerytów produktem bankom jest rachunek bankowy z którego korzystało 95\% respondentów (Raport InfoSenior 2019, s. 5).
} 
jednak niższa o niecałe 2 punkty procentowe od średniego poziomu ubankowienia Polaków ${ }^{26}$. Należy również zaznaczyć, że odsetek uczestniczących w badaniach kobiet, które posiadały rachunek bankowy $(83,7 \%)$ był o ponad 4 punkty procentowe niższy od średniego poziomu ubankowienia kobiet w Polsce.

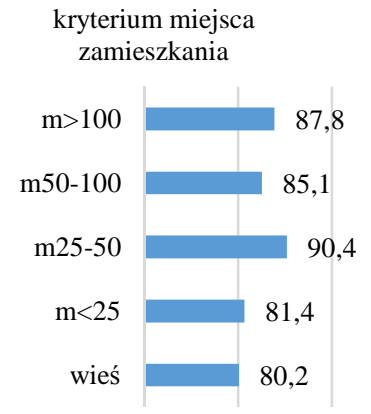

$60 \quad 80 \quad 100$

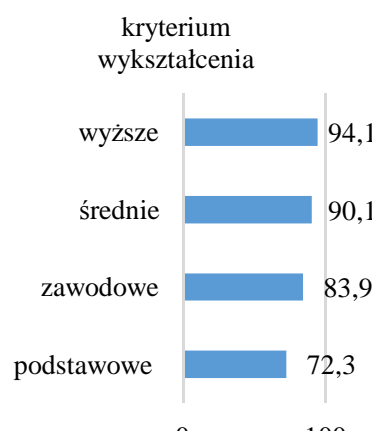

$0 \quad 100$

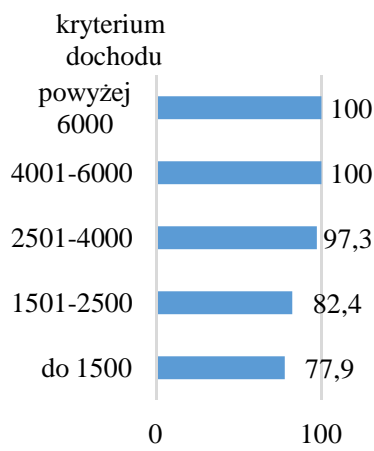

100

Rysunek 4. Odsetek respondentów posiadających rachunek bankowy. Źródło: opracowanie na podstawie badań własnych.

Analizując liczbę respondentów posiadających rachunek bankowy (rys. 4) stwierdzono, że procentowy udział posiadaczy rachunków rósł wraz ze wzrostem wykształcenia respondentów oraz uzyskiwanych przez nich dochodów. Natomiast analizując miejsce zamieszkania ankietowanych stwierdzono, że najmniej posiadaczy rachunków bankowych mieszkało na wsi $(80,2 \%)$ a najwięcej w miastach od 25 do 50tysięcy mieszkańców $(90,4 \%)$.

Respondenci, którzy zadeklarowali, że nie posiadają rachunku bankowego twierdzili, że jest to spowodowane przede wszystkim: brakiem takiej potrzeby $(61,6 \%)$, brakiem odpowiednich środków $(54,6 \%)$ oraz preferowaniem realizacji płatności gotówką (45,3\%). Trzeba zaznaczyć, że na brak potrzeby posiadania rachunku bankowego oraz preferowanie płatności gotówką częściej wskazywali mężczyźni ${ }^{27}$ a na brak odpowiednich środków kobiety ${ }^{28}$. Uczestnicy badań wskazywali również na: posiadanie rachunku bankowego przez współmałżonka (27,9\%), brak zaufania do instytucji bankowych $(24,4 \%)$, brak dogodnej lokalizacji placówek bankowych $(19,8 \%)$ oraz wysokość opłat i prowizji $(12,8 \%)^{29}$.

\footnotetext{
${ }^{26}$ Poziom ubankowienia w Polsce obywateli powyżej 15 roku życia w 2018 r. wynosił 86,7\%. Zobacz: The Little 2018...op. cit., s.125.

${ }^{27} \mathrm{Na}$ brak potrzeby posiadania rachunku bankowego wskazało $54,9 \%$ kobiet oraz $71,4 \%$ mężczyzn nieposiadających rachunku bankowego. Natomiast preferowanie płatności gotówką wymieniło $27,4 \%$ kobiet oraz 71,4\% mężczyzn.

${ }^{28} \mathrm{Na}$ brak odpowiednich środków wskazało $60,8 \%$ kobiet oraz 45,7\% mężczyzn nieposiadających rachunku bankowego.

${ }^{29} \mathrm{Na}$ posiadanie rachunku bankowego przez współmałżonka wskazywało 37,3\% kobiet oraz 14,3\% mężczyzn, na brak zaufania do instytucji bankowych $27,4 \%$ kobiet oraz $20 \%$ mężczyzn, na brak dogodnej lokalizacji placówek bankowych 21,6\% kobiet oraz 17,1\% mężczyzn a na wysokość opłat i prowizji 7,8\% kobiet oraz $20 \%$ mężczyzn.
} 
Interesującym jest również fakt, że w analizowanej grupie badawczej znajdowało się aż $8,1 \%$ respondentów, którzy równocześnie zadeklarowali, że posiadają rachunek bankowy i nie korzystają z usług bankowych. Zaznaczenia wymaga, że takie zachowanie cechowało głównie kobiety ${ }^{30}$.

Tabela 2. Struktura grupy badawczej ze względu na liczbę banków, z usług których równocześnie korzystają respondenci w procentach

\begin{tabular}{|c|c|c|c|c|c|}
\hline Wyszczególnieni & $\begin{array}{c}\text { Nie } \\
\text { korzysta } \\
\text { usług banku }\end{array}$ & $\begin{array}{l}\text { Korzysta z } \\
\text { usł. } 1 \text { banku }\end{array}$ & $\begin{array}{c}\text { Korzysta z } \\
\text { usł. } 2 \\
\text { banków }\end{array}$ & $\begin{array}{c}\text { Korzysta z } \\
\text { usł. } 3 \\
\text { banków }\end{array}$ & $\begin{array}{c}\text { Korzysta z } \\
\text { usł. } 4 \text { i } \\
\text { więcej } \\
\text { banków }\end{array}$ \\
\hline \multicolumn{6}{|l|}{ kryterium ptci } \\
\hline kobiety & 16,29 & 71,25 & 9,27 & 2,88 & 0,32 \\
\hline mężczyźni & 13,67 & 64,45 & 13,67 & 7,03 & 1,17 \\
\hline \multicolumn{6}{|c|}{ kryterium miejsca zamieszkania } \\
\hline wieś & 19,82 & 72,07 & 7,21 & 0,90 & 0 \\
\hline miasto do 25 tys. & 18,64 & 65,25 & 12,71 & 3,39 & 0 \\
\hline miasto $25-50$ tys. & 9,62 & 73,08 & 11,54 & 4,81 & 0,96 \\
\hline miasto $50-100$ tys. & 14,88 & 63,64 & 13,22 & 7,44 & 0,83 \\
\hline miasto pow. 100 tys. & 12,17 & 67,83 & 11,30 & 6,96 & 1,74 \\
\hline \multicolumn{6}{|c|}{ kryterium wyksztatcenia } \\
\hline podstawowe & 27,66 & 69,15 & 3,19 & 0 & 0 \\
\hline zawodowe & 16,05 & 76,95 & 5,35 & 1,65 & 0 \\
\hline średnie & 9,94 & 62,98 & 17,13 & 8,84 & 1,10 \\
\hline wyższe & 5,88 & 43,14 & 33,33 & 13,73 & 3,92 \\
\hline \multicolumn{6}{|l|}{ kryterium dochodu } \\
\hline do 1500 PLN & 22,12 & 76,96 & 0,92 & 0 & 0 \\
\hline 1501-2500 PLN & 17,59 & 78,89 & 3,52 & 0 & 0 \\
\hline 2501-4000 PLN & 2,70 & 54,95 & 27,93 & 13,51 & 0,9 \\
\hline 4001-6000 PLN & 0 & 0 & 58,62 & 31,03 & 10,34 \\
\hline pow. 6000 PLN & 0 & 23,08 & 53,85 & 23,08 & 0 \\
\hline
\end{tabular}

Źródło: opracowanie na podstawie badań własnych.

Analizując liczbę banków z usług których respondenci równocześnie korzystają (tabela 2) należy stwierdzić, że ponad $68 \%$ respondentów stwierdziło, że korzysta $\mathrm{z}$ usług tylko jednego banku ${ }^{31}$. Deklarację taką częściej składały kobiety ${ }^{32}(71,2 \%)$ niż mężczyźni ${ }^{33}(64,4 \%)$. Natomiast z większej liczby banków częściej korzystali mężczyźni $(21,9 \%)$ niż kobiety (12,5\%). Najczęściej z usług kilku banków korzystali respondenci legitymujący się wyższym wykształceniem (51\% kobiet oraz 72,7\% mężczyzn) oraz ankietowani mieszkający w dużych miastach (kobiety mieszkające w miastach powyżej 100-tysięcy mieszkańców $(17,7 \%)$ oraz mężczyźni mieszkający w miastach 50-100 tysięcy $(30,8 \%))$.

\footnotetext{
${ }^{30}$ Równocześnie na posiadanie rachunku bankowego oraz nie korzystanie z usług bankowych wskazało $13,4 \%$ kobiet oraz $1,81 \%$ mężczyzn.

${ }^{31}$ Korzystanie z usług tylko jednego banku zadeklarowało $80,3 \%$ respondentów $(85,1 \%$ kobiet oraz $74,7 \%$ mężczyzn), którzy posiadali rachunki bankowe.

${ }^{32} \mathrm{Z}$ usług jednego banku najczęściej korzystały kobiety mieszkające w miastach 25-50-tysięcy mieszkańców $(80,8 \%)$, respondentki posiadające wykształcenie zawodowe $(80,7 \%)$, ankietowane osiągające dochody w przedziale od 1501 do 2500 PLN $(83,6 \%)$.

33 Z usług jednego banku najczęściej korzystali mężczyźni mieszkający na wsi (78,6\%), respondenci posiadający wykształcenie zawodowe $(73,4 \%)$, ankietowani osiągający dochody poniżej 1500 PLN $(84,6 \%)$.
} 
Wiek respondentów gdy zakładali pierwszy rachunek bankowy

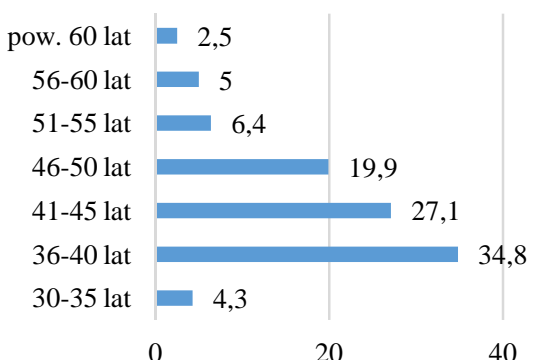

Nadal korzystający z usług banku w którym założyli pierwszy rachunek bankowy

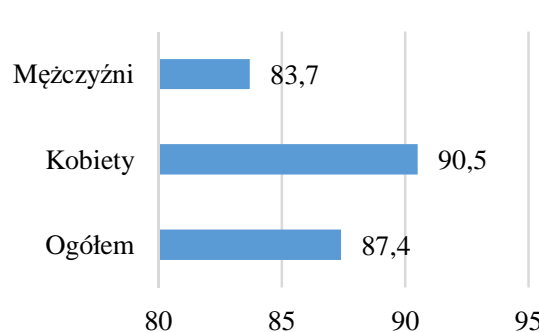

$80 \quad 85 \quad 90 \quad 95$

Rysunek 5. Struktura wieku respondentów w jakim założyli pierwszy rachunek bankowy w procentach oraz odsetek nadal korzystających z usług banku, w którym założyli pierwszy rachunek.

Źródło: opracowanie na podstawie badań własnych.

System gospodarczy, obowiązujący sposób wypłaty wynagrodzeń oraz płatności za towary i usługi, rozwój systemu bankowego oraz zakres świadczonych przez banki usług w Polsce w drugiej połowie XX wieku miał znaczący wpływ na fakt, że uczestniczące w badaniach osoby pierwsze rachunki bankowe zakładały dopiero po ukończeniu 30 roku życia $^{34}$ (rys. 5). Należy zaznaczyć, że w analizowanej grupie badawczej do 35 roku życia rachunek bankowy posiadało tylko 4,3\% ankietowanych a do 40 roku życia $39,13 \%$ respondentów. Najczęściej posiadanie rachunku przed 40 rokiem życia deklarowali mieszkańcy miast powyżej 100-tysięcy mieszkańców (56,4\% - 53,9\% kobiet oraz $60 \%$ mężczyzn) oraz ankietowani legitymujący się wyższym wykształceniem (64,6\% - 74,1\% kobiet oraz 52,4\% mężczyzn). Najrzadziej zaś mieszkańcy wsi (7,9\% $6 \%$ kobiet oraz $10,2 \%$ mężczyzn) oraz respondenci posiadający wykształcenie podstawowe $(7,3 \%$ - 11,5\% kobiet oraz 4,8\% mężczyzn). Ponad $86 \%$ respondentów posiadających rachunek bankowy (85,5\% kobiet oraz 86,9\% mężczyzn) stwierdziło, że pierwszy rachunek bankowy założyło przed 50 rokiem życia. Trzeba zauważyć, że późny wiek w jakim ankietowani zakładali pierwszy rachunek bankowy mógł wynikać również $\mathrm{z}$ faktu, że podstawowym powodem założenia rachunku nie było „poczucie takiej potrzeby” ale „wymagania pracodawcy ${ }^{35, "}$.

Należy podkreślić, że biorących udział $\mathrm{w}$ badaniach przedstawicieli mieszkańców Polski zaliczanych do generacji $65+$ cechował bardzo wysoki poziom lojalności do banku, w którym założyli pierwszy rachunek bankowy w życiu. Ponad 87\% respondentów zadeklarowało, że nadal korzysta z usług tego banku (rys. 5).

Analizując poziom lojalności ankietowanych przy uwzględnieniu kryterium posiadanego wykształcenia stwierdzono, że zmniejszał się on wraz ze wzrostem

\footnotetext{
${ }^{34}$ Żaden uczestnik badań nie zadeklarował posiadania rachunku bankowego przed ukończeniem 30 roku życia. ${ }^{35} \mathrm{Na}$ wymagania pracodawcy jako podstawowy powód założenia rachunku bankowego wskazało aż $64,6 \%$ uczestników badań deklarujących posiadanie takiego rachunku.
} 
poziomu wykształcenia respondentów $\mathrm{w}^{36}$. Analogicznie sytuacja przedstawiała się w przypadku kryterium miejsca zamieszkania. Poziom lojalności zmniejszał się wraz ze wzrostem liczby mieszkańców zamieszkiwanej miejscowości ${ }^{37}$. Niewątpliwe było to związane $\mathrm{z}$ bardziej rozbudowaną siecią placówek bankowych $\mathrm{w}$ większych aglomeracjach. Natomiast biorąc pod uwagę osiągany dochód najwyższym poziomem lojalności cechowały się kobiety osiągające dochody do 1500 PLN $(92,1 \%)$ oraz mężczyźni posiadający dochód w przedziale od 1501-2500 PLN (91\%).

\section{Produkty depozytowe}

Ponad 54\% uczestniczących w badaniach przedstawicieli pokolenia $65+$ zadeklarowało, że nie korzysta $\mathrm{z}$ oferowanych przez banki produktów depozytowych ${ }^{38}$. Zapewne bezpośredni wpływ na to miał poziom osiąganych przez uczestników badań dochodów (dochód do 1500 PLN zadeklarowało 38,1\% respondentów a od 1501 do 2500 PLN 35\% ankietowanych) oraz ich bieżące potrzeby konsumpcyjne. Należy pamiętać, że przedstawicieli tego pokolenia określa się, że są oni bogaci kapitałowo ${ }^{39}$ ale równocześnie ubodzy dochodowo ${ }^{40}$.

W segmencie kobiet najwięcej respondentek, które były wykluczone z korzystania z produktów depozytowych oferowanych przez banki znajdowało się wśród: kobiet mieszkających w miastach 50-100-tysięcy mieszkańców (63,8\%), posiadających wykształcenie zawodowe $(68,9 \%)$ o dochodach nie przekraczających 1500 PLN $(81,3 \%)$. Natomiast w segmencie mężczyzn wśród: mieszkańców miast 25-50-tysięcy mieszkańców $(55,8 \%)$, legitymujących się wykształceniem podstawowym $(61,8 \%)$ o dochodach nie przekraczających 1500 PLN (70,5\%).

\footnotetext{
${ }^{36}$ Najwyższym poziomem lojalności charakteryzowali się ankietowani posiadający wykształcenie podstawowe (94,1\% - 96,1\% kobiet oraz 92,8\% mężczyzn). Najniższym natomiast respondenci legitymujący się wyższym wykształceniem $(81,2 \%$ - $81,5 \%$ kobiet oraz $80,9 \%$ mężczyzn).

${ }^{37}$ Najwyższy poziomem lojalności cechowali się mieszkańcy wsi (93,3\% - 94\% kobiet oraz 92,3\% mężczyzn). Najniższym zaś mieszkańcy miast ponad 100-tysięcy mieszkańców $(84,2 \%$ - 86,3\% kobiet oraz $82 \%$ mężczyzn).

${ }^{38}$ W 2014 r. w segmencie 65+ depozyty posiadało 68,2\% gospodarstw domowych. Jednak przeciętna wartość tych depozytów była niska i wynosiła 5 tys. PLN. Zobacz B. Świecka: Ocena sytuacji...op. cit., s.127.

W przeprowadzonych w 2012 r. badaniach tylko $12 \%$ respondentów z grupy wiekowej 65 - 74 lat oraz $10 \%$ ankietowanych z grupy wiekowej ponad 75 lat stwierdziło, że celem ich wizyty w banku jest założenie lokaty. Z kolei aktualne posiadanie lokaty zadeklarowało $16 \%$ respondentów z grupy wiekowej $65-74$ lat oraz 10\% ankietowanych z grupy wiekowej ponad 75 lat. Zobacz D. Maison: Badanie postaw...op. cit., s. 3031.

Natomiast w badania przeprowadzone w grudniu 2018 r. 35\% respondentów zadeklarowało posiadanie lokaty a 46\% ankietowanych konta oszczędnościowego. Zobacz Raport InfoSenior 2019, s. 5.

${ }^{39} \mathrm{~W}$ Polsce bogactwo kapitałowe zazwyczaj stanowią nieruchomości i ruchomości zgromadzone w okresie pracy zawodowej. Dla przykładu badania Zasobności Gospodarstw Domowych w 2016 r. wykazały, że 83,7\% osób w wieku 65 - 74 lata oraz 90,3\% osób w wieku 75+ jest właścicielami swojego miejsca zamieszkania. Zobacz: Zasobność gospodarstw domowych w Polsce. Raport z badań 2016 r.. Narodowy Bank Polski, Warszawa 2017, s. 94.

${ }^{40}$ Przeciętne miesięczne dochody na 1 osobę w gospodarstwach domowych złożonych wyłącznie z osób w wieku ponad 60 lat w 2017 r. wynosiły 1888,76 PLN. Zobacz Informacja o sytuacji osób starszych w Polsce za rok 2016. Sejm RP, Druk nr 2043, Warszawa 2017, s.12.
} 
Tabela 3. Odsetek respondentów ze względu na korzystanie z produktów depozytowych

\begin{tabular}{|l|c|c|c|}
\hline \multicolumn{1}{|c|}{ Produkty depozytowe } & Ogółem & Kobiety & Mężczyźni \\
\hline brak depozytów & 54,48 & 61,34 & 46,09 \\
\hline lokata do 1 miesiąca & 0,88 & 0,32 & 1,56 \\
\hline lokata do 3 miesięcy & 11,07 & 8,31 & 14,45 \\
\hline lokata 3 - 6 miesięcy & 16,34 & 12,14 & 21,48 \\
\hline lokata 6 miesięcy - 1 roku & 11,42 & 12,46 & 10,16 \\
\hline lokata powyżej 1 roku & 2,46 & 2,88 & 1,95 \\
\hline inne depozyty & 3,34 & 2,56 & 4,30 \\
\hline
\end{tabular}

Źródło: opracowanie na podstawie badań własnych.

Przeprowadzona analiza poziomu zainteresowania wśród respondentów korzystaniem z produktów depozytowych wykazała, że rósł on wraz ze wzrostem posiadanego przez ankietowanych dochodu ${ }^{41}$ oraz wykształcenia ${ }^{42}$. Natomiast wykorzystując do analizy miejsce zamieszkania respondentów stwierdzono, że największy odsetek ankietowanych korzystających z tego rodzaju produktów mieszkał na wsi $(48,6 \%)$ oraz w miastach powyżej 100-tysięcy mieszkańców (47\%) a najmniejszy w miastach 25-50-tysięcy mieszkańców (41,3\%).

Z kolei analizując wyłącznie grupę respondentów, która zadeklarowała, że korzysta z produktów depozytowych stwierdzono, że największym zainteresowaniem cieszyły się lokaty 3 - 6 miesięczne (35,9\% - 31,4\% kobiety oraz 39,9\% mężczyźni). Na korzystanie $\mathrm{z}$ tego rodzaju lokat najczęściej wskazywali mieszkańcy wsi $(46,3 \%)$ oraz miast ponad 100-tysięcy mieszkańców (40,7\%), respondenci legitymujący się średnim wykształceniem (49,4\%), ankietowani posiadający dochód w przedziale 1501 - 2500 PLN (44,8\%). Na kolejnych miejscach ankietowani wymieniali lokaty o terminie zapadalności od 6 miesięcy do 1 roku $(25,1 \%$ - 32,2\% kobiet oraz 18,8\% mężczyzn) oraz lokaty o terminie zapadalności do 3 miesięcy $(24,3 \%$ - 21,5\% kobiet oraz 26,8\% mężczyzn).

Zaznaczenia wymaga również fakt, że posiadanie w swoim portfelu lokat do 1 miesiąca oraz innych depozytów deklarowali prawie wyłącznie ankietowani, których dochody wynosiły co najmniej 4000 PLN.

\section{Produkty kredytowe}

Przedstawicieli pokolenia 65+ uczestniczących w badaniach ankietowych cechuje niewielka aktywność $\mathrm{W}$ korzystaniu $\mathrm{z}$ oferowanych przez banki produktów kredytowych $^{43}$ (tabela 4). Tylko ok. $18 \%$ respondentów (18,8\% kobiet oraz 17,2\%

${ }^{41}$ Odsetek respondentów korzystających z produktów depozytowych w zależności od posiadanego dochodu wynosił odpowiednio: 22,6\% (przy dochodach do 1500 PLN), 43,7\% (przy dochodach 1501-2500 PLN), $75,7 \%$ (przy dochodach 2501-4000), 89,7\% (przy dochodach 4001-6000), 100\% (przy dochodach ponad 6000 PLN).

${ }^{42}$ Odsetek ankietowanych korzystających $\mathrm{z}$ produktów depozytowych w zależności od posiadanego wykształcenia wynosił odpowiednio: 36,2\% (wykształcenie podstawowe), 40,7\% (wykształcenie zawodowe), 49,2\% (wykształcenie średnie), 72,5\% (wykształcenie wyższe).

${ }^{43}$ Zgodnie z informacjami Krajowego Rejestru Dłużników na koniec 2018 r. było zarejestrowanych w nim ok. 328 tysięcy emerytów, których łączne zadłużenie wynosiło 5,6 mld PLN.

Natomiast według danych BIK na koniec 2018 r. kredyt lub pożyczkę posiadało 2,88 mln osób w wieku powyżej 65 lat. Około 70\% wartości zobowiązań seniorów zaciągniętych w bankach to kredyty gotówkowe i ratalne. Średnie łączne zadłużenie z tytułu aktualnej kwoty do spłaty posiadanych kredytów i pożyczek 
mężczyzn) zadeklarowało, że po ukończeniu 65 roku życia nadal korzystało z tego rodzaju produktów bankowych ${ }^{44}$. Największą aktywnością na tym polu cechowali się mieszkańcy miast powyżej 100-tysięcy mieszkańców (22,6\%), ankietowani legitymujący się wyższym wykształceniem $(33,3 \%)$ oraz respondenci o dochodach w przedziale od 1501 do 2500 PLN (24,1\%). Analiza uzyskanych wyników pozwala na stwierdzenie, że w segmencie kobiet odsetek respondentek korzystających z produktów kredytowych zwiększał się wraz ze wzrostem wielkości zamieszkiwanej miejscowości a w segmencie mężczyzn wraz ze wzrostem poziomu wykształcenia ankietowanych.

Tabela 4. Odsetek respondentów ze względu na korzystanie z produktów kredytowych

\begin{tabular}{|l|c|c|c|}
\hline Produkty kredytowe & Ogółem & Kobiety & Mężczyźni \\
\hline nie korzysta z produktów kredytowych & 81,90 & 81,15 & 82,81 \\
\hline limit w koncie & 6,68 & 6,71 & 6,64 \\
\hline karta kredytowa & 4,04 & 4,79 & 3,13 \\
\hline kredyt gotówkowy & 5,80 & 6,07 & 5,47 \\
\hline kredyt samochodowy & 2,64 & 1,92 & 3,52 \\
\hline kredyt hipoteczny & 1,41 & 0,64 & 2,34 \\
\hline inne & 1,58 & 1,28 & 1,95 \\
\hline
\end{tabular}

Źródło: opracowanie na podstawie badań własnych.

Analizując odpowiedzi udzielone wyłącznie przez respondentów, którzy zadeklarowali, że aktualnie korzystają z produktów kredytowych stwierdzono, że największym zainteresowaniem cieszył się przyznany przez bank limit w koncie (36,9\% - 35,6\% kobiet oraz 38,6\% mężczyzn). Na kolejnych miejscach ankietowani wymieniali kredyt gotówkowy (32\% - 32,2\% kobiet oraz 31,8\% mężczyzn) oraz kredyt w karcie kredytowej (22,3\% - 25,4\% kobiet oraz 18,2\% mężczyzn). Co siódmy przedstawiciel tego segmentu uczestników badań korzystał z kredytu samochodowego a co trzynasty z kredytu hipotecznego. Z obu tych rodzajów kredytów częściej korzystali mężczyźni niż kobiety.l

\section{Karty bankowe}

W analizowanej grupie ok. $80 \%$ respondentów zadeklarowało posiadanie karty bankowej. Częściej posiadanie dowolnej karty bankowej deklarowali mężczyźni $(84,8 \%)$ niż kobiety $(75,1 \%)$. Wpływ na występowanie tak dużej liczby wśród ankietowanych posiadaczy kart bankowych na pewno ma fakt, że aktualnie klienci banków wraz $\mathrm{z}$ założeniem rachunku bieżącego mogą otrzymać związane z nim karty bankowe. Zazwyczaj jest to karta debetowa oraz karta kredytowa.

wynosi 10614 zł na osobę. Zobacz Kredytowy portret polskiego seniora. (2019). https://media.bik.pl/informacje-prasowe/418009/kredytowy-portret-polskiego-seniora (data wejścia: 20.02.2019)

${ }^{44} \mathrm{~W}$ badaniach w 2012 r. tylko $14 \%$ respondentów z grupy wiekowej 65 - 74 lat oraz 3\% ankietowanych z grupy wiekowej ponad 75 lat wyraziło chęć zaciągnięcie kredytu. Natomiast $14 \%$ respondentów z grupy wiekowej $65-74$ lat oraz 6\% ankietowanych z grupy wiekowej ponad 75 lat zadeklarowało, że ma aktualnie zaciągnięty kredyt. Zobacz D. Maison: Badanie postaw...op. cit., s. 30-31.

W badania przeprowadzone w grudniu 2018 r. 28\% respondentów zadeklarowało zaciągnięcie kredytu lub pożyczki a 8\% ankietowanych zaciągnięcie kredytu hipotecznego. Zobacz Raport InfoSenior 2019, s. 5. 
Tabela 5. Odsetek posiadaczy karty bankowej wśród posiadaczy konta bankowego

\begin{tabular}{|l|c|c|c|}
\hline Rodzaj karty bankowej & Ogółem & Kobiety & Mężczyźni \\
\hline karty obciążeniowej & 2,28 & 1,91 & 2,71 \\
\hline karty lojalnościowej & 2,90 & 4,58 & 0,90 \\
\hline karty przedpłaconej & 4,35 & 5,73 & 2,71 \\
\hline karty kredytowej & 17,18 & 18,32 & 15,84 \\
\hline karty debetowej & 93,58 & 89,69 & 98,19 \\
\hline
\end{tabular}

Źródło: opracowanie na podstawie badań własnych.

W analizowanej grupie badawczej w segmencie respondentów posiadających rachunek bankowy odsetek posiadaczy karty debetowej wynosił aż 93,58\%. A w przypadku karty kredytowej 17,18\% (tabela 5). Należy jednak zaznaczyć, że aktywność w posługiwaniu się tymi kartami przez respondentów nie była wysoka ${ }^{45}$. Tylko 45,13\% ankietowanych co najmniej raz w miesiącu posługiwało się kartą debetową. Podobny poziom aktywności (46,99\%) został zadeklarowany przez respondentów posiadających karty kredytowe ${ }^{46}$ (tabela 6).

Tabela 6. Odsetek aktywnych posiadaczy kart bankowych wśród posiadaczy rachunków bankowych oraz wśród posiadaczy kart

\begin{tabular}{|c|c|c|c|}
\hline & Ogółem & Kobiety & Mężczyźni \\
\hline \multicolumn{4}{|l|}{ Posiadacze rachunku bankowego } \\
\hline korzysta z karty debetowej & 42,24 & 40,84 & 43,89 \\
\hline korzysta z karty kredytowej & 8,07 & 9,16 & 6,79 \\
\hline korzysta z karty lojalnościowej & 1,04 & 1,53 & 0,45 \\
\hline korzysta z karty obciążeniowej & 2,28 & 1,91 & 2,71 \\
\hline korzysta z karty przedpłaconej & 3,73 & 4,58 & 2,71 \\
\hline \multicolumn{4}{|l|}{ Posiadacze danego rodzaju karty } \\
\hline korzysta z karty debetowej & 45,13 & 45,53 & 44,70 \\
\hline korzysta z karty kredytowej & 46,99 & 50 & 42,86 \\
\hline korzysta z karty lojalnościowej & 35,71 & 33,33 & 50 \\
\hline korzysta z karty obciążeniowej & 100 & 100 & 100 \\
\hline korzystam z karty przedpłaconej & 85,71 & 80 & 100 \\
\hline
\end{tabular}

Źródło: opracowanie na podstawie badań własnych.

Nieliczni przedstawiciele pokolenia $65+$ zadeklarowali, że posiadają i pokorzystają z innych rodzajów kart bankowych: przedpłaconej $(4,35 \%)$, lojalnościowej $(2,9 \%)$ oraz obciążeniowej $(2,28 \%)$. Należy również podkreślić, że posiadaczy tego rodzaju kart cechuje wysoki poziom aktywności w korzystaniu z nich.

${ }^{45}$ W 2018 z karty debetowej korzystało w Polsce 52\% osób powyżej 59 roku życia a z karty kredytowej $28 \%$. (Raport InfoSenior 2018, s.15). Natomiast w grudniu 2018 r. posiadanie karty płatniczej zadeklarowało w 52\% respondentów (Raport InfoSenior 2019, s. 5).

${ }^{46}$ Posiadanie karty kredytowej zadeklarowało 14,6\% uczestników badań (15,3\% kobiet oraz 13,7\% mężczyzn). Interesującym jest fakt, że korzystanie $\mathrm{z}$ tego produktu potwierdziło $6,8 \%$ badanych $(7,7 \%$ kobiet oraz $5,9 \%$ mężczyzn). Natomiast na korzystanie z kredytu w karcie kredytowej wskazało tylko 4,\% ankietowanych $(4,8 \%$ kobiet oraz 3,1\% mężczyzn). 


\section{Podsumowanie}

Wiek i poziom posiadanej wiedzy finansowej potencjalnych klientów może mieć znaczący wpływ na strukturę potrzeb i oczekiwań odnośnie portfela usług bankowych. Czynniki te mają istotny wpływ na proces segmentacji klientów, który jest niezbędny dla poznania indywidulnych cech i oczekiwań homogenicznych grup. Działania te pozwalają na opracowanie spersonalizowanego portfela produktów, który może stanowić podstawę sukcesu banku. Dlatego banki w swoich działaniach nie mogą zapominać o grupie najstarszych klientów szczególnie w kontekście dynamicznego wzrostu znaczenia tzw. srebrnej ekonomii.

Banki nie powinny też tej coraz większej grupy klientów pozostawiać na marginesie swojej działalności uważając, że przedstawiciele seniorów zadowolą się standardowymi produktami $^{47}$. Biorąc pod uwagę, że największym zainteresowaniem wśród tego segmentu klientów cieszy się rachunek bankowy ${ }^{48}$ muszą przede wszystkim skupić się na czerpaniu zysków z obsługi codziennej tworząc przyjazny - konkurencyjny sposób realizacji płatności czy też np. dostarczania gotówki do domu. Opracowując dodatkowe pakiety pomocne dołączane do rachunków bankowych powinny je „skroić na miarę" potrzeb pokolenia $65+$. Badania wykazały, że ankietowani za takie produkty są skłonni ponieść znaczne co miesięczne opłaty ${ }^{49}$. Wymagają oni jednak w zamian za to zrozumiałej formy przekazu informacji o produktach bankowych i jasno sformułowanych umów ${ }^{50}$ oraz ,,szacunku” przejawiającego się m.in. tym, że bank za gorszej jakości usługę od usługi standardowej nie będzie oczekiwał od nich wyższego wynagrodzenia.

W mniejszym stopniu banki powinny oczekiwać zysków osiąganych z tytułu korzystania przez przedstawicieli pokolenia $65+\mathrm{z}$ produktów depozytowych i kredytowych. Muszą przy tym pamiętać, że zasobność osób starszych w Polsce jest, na tle krajów strefy euro, stosunkowo niska a majątek ich składa się w decydującym stopniu $\mathrm{z}$ aktywów rzeczowych, przy niewielkim udziale aktywów finansowych ${ }^{51}$. Powoduje to, że mniejszy odsetek klientów należących do tego segmentu będzie zakładał lokaty a wysokość tych lokat będzie stosunkowo niska. Natomiast w przypadku kredytów muszą wziąć pod uwagę fakt, że chociaż seniorzy co miesiąc otrzymają stałe i pewne wynagrodzenie w postaci emerytury to jej wysokość nie pozwala im zaciągać dużych kredytów na krótki okres czasu.

Reasumując banki opracowując portfel produktów dedykowanych dla seniorów muszą również uwzględnić fakt, że aktualnie tę grupę stanowią w zdecydowanej większości osoby zaliczane do generacji baby boomers. Jednak w najbliższych latach

\footnotetext{
$4747,3 \%$ respondentów (43,1\% kobiet oraz 48,4\% mężczyzn) było zainteresowanych posiadaniem rachunku bankowego dedykowanego dla seniorów.

${ }^{48}$ Zgodnie z informacją ZUS $69 \%$ emerytów otrzymuje emeryturę na rachunek bankowy.

${ }^{49} 22,3 \%$ ankietowanych akceptuje opłatę za rachunek bankowy w wysokości 10-15 PLN, 25,5\% respondentów w wysokości 15-25 PLN a 8,3\% w wysokości ponad 25 PLN.

${ }^{50} 66,1 \%$ respondentów (70\% kobiet oraz $61,3 \%$ mężczyzn) oceniając stopień skomplikowania przekazu informacji o produktach bankowych wybrało odpowiedzi duży $(45,2 \%)$ lub bardzo duży $(20,9 \%)$. Natomiast $75,6 \%$ ankietowanych $(77,3 \%$ kobiet oraz $73,4 \%$ mężczyzn) dokonując oceny poziomu skomplikowania umów bankowych wskazało na odpowiedzi duży $(43,1 \%)$ i bardzo duży $(32,5 \%)$.

${ }^{51}$ Świecka B.: Ocena sytuacji finansowej osób starszych w Polsce ze szczególnym uwzględnieniem zasobności i zadłużenia. Problemy Zarządzania, vol. 14, nr 2 (59)/2016
} 
dołączą do nich przedstawiciele generacji X, których oczekiwania co do formy i zakresu realizowanych usług bankowych nie pokrywają się $\mathrm{w}$ całości $\mathrm{z}$ dotychczasowymi wzorcami. Dlatego już dziś powinny podjąć działania mające na celu budowę optymalnego dla tej grupy portfela produktów.

\section{Literatura}

Anderloni, L.: Access to Bank Account and Payment Services. [w:] L. Anderloni, M.D. Braga, E.M. Carluccio (red.): New Frontiers in Banking Services. Emerging Needs and Tailored Products for Untapped Markets. Springer - Verlag, Berlin-Heidelberg 2007.

Connolly C., Hajjaj, K.: Financial Services and Social Exclusion. Financial Services Consumer Policy Centre. University of New South Wales Sydney 2001.

Financial Services Provision and Prevention of Financial Exclusion, EC Report VC/2006/0183, European Commission, Brussels 2008.

Golinowska S., Srebrna gospodarka - ekonomiczny wymiar procesu starzenia się populacji. (w:) Strategie działania w starzejącym się społeczeństwie. Tezy i rekomendacje. Rzecznik Praw Obywatelskich, Warszawa 2012.

Growing the European Silver Economy. Background Paper. European Commission 2015.

Informacja o sytuacji osób starszych w Polsce za rok 2016. Sejm RP, Druk nr 2043, Warszawa 2017.

Kredytowy portret polskiego seniora. (2019). https://media.bik.pl/informacje-

prasowe/418009/kredytowy-portret-polskiego-seniora (data wejścia: 20.02.2019)

Leyshon, A., Thrift, N.: Geographies of financial exclusion: financial abandonment in Britain and United States, Transactions of the Institute of British Geographers, "New Series", 20/1995.

Maison D.: Badanie postaw Polaków powyżej 60. roku życia wobec obrotu bezgotówkowego raport z badań. Narodowy Bank Polski, Warszawa 2012.

Maison D.: Postawy Polaków wobec obrotu bezgotówkowego. (2017). http://www.nbp.pl/ home.aspx?f=/systemplatniczy/obrot_bezgotowkowy/obrot_bezgotowkowy.html (data wejścia: 20.02.2019)

Osoby starsze na rynku usług finansowych - analiza i zalecenia. Biuletyn Rzecznika Praw Obywatelskich 2013, nr 4.

Richardson, L., Le Grand, J.: Outsider and insider perspective: The Response of Residents of Deprived Neighbourhoods to an Academic Definition of Social Exclusion. CASE Papers 57, London School of Economics, Centre for Analysis of Social Exclusion 2002.

The Little Data Book on Financial Inclusion. International Bank for Reconstruction and Development / The World Bank, Washington 2018.

Porównanie wybranych elementów polskiego systemu płatniczego z systemami innych krajów Unii Europejskiej za 2017 r.. Narodowy Bank Polski, Warszawa 2018.

Raport InfoSenior (2018). Związek Banków Polskich.

https://zbp.pl/public/repozytorium/wydarzenia/.../ZBP_InfoSenior_18.01_f.pdf (data wejścia: 20.02.2019)

Raport InfoSenior (2019). Związek Banków Polskich. https://zbp.pl/public/repozytorium/...2019/ZBP_InfoSenior_2019_POPR_21.01.pdf (data wejścia: 20.02.2019)

Raport PRNews.pl: ROR-y w 2011: największy wzrost w Aliorze, Pocztowym i Millennium. https://prnews.pl/ror-y-w-2011-najwiekszy-wzrost-w-aliorze-pocztowym-i-millennium-25291 (data wejścia: 20.02.2019)

Raport PRNews.pl: Rynek kont osobistych - IV kw. 2013. https://prnews.pl/raport-prnews-plrynek-kont-osobistych-iv-kw-2013-16267 (data wejścia: 20.02.2019) 
Raport PRNews.pl: Rynek kont osobistych - IV kw. 2015. https://prnews.pl/raport-prnews-plrynek-kont-osobistych-iv-kw-2015-2462 (data wejścia: 20.02.2019)

Raport PRNews.pl: Rynek kont osobistych - IV kw. 2017. https://prnews.pl/raport-prnews-plrynek-kont-osobistych-iv-kw-2017-434129 (data wejścia: 20.02.2019)

Raport PRNews.pl: Rynek kont osobistych - IV kw. 2018. https://prnews.pl/raport-prnews-plrynek-kont-osobistych-iv-kw-2018-441689 (data wejścia: 20.02.2019)

Rocznik demograficzny. (2018). Główny Urząd Statystyczny, Warszawa 2018.

Sinclair, S: Financial Exclusion: An Introductory Survey. Centre for Research into Socially Inclusive Services (CRSIS). Edinburgh College of Art/Heriot Watt University Edinburgh 2001.

Sołtysiak M.: Zjawisko wykluczenia finansowego w opiniach przedstawicieli pokolenia baby boombers. Zeszyty Naukowe Wydziału Nauk Ekonomicznych Politechniki Koszalińskiej nr 21/2017.

Świecka B.: Ocena sytuacji finansowej osób starszych w Polsce ze szczególnym uwzględnieniem zasobności i zadłużenia. Problemy Zarządzania, vol. 14, nr 2 (59)/2016, DOI 10.7172/16449584.59.8

Zasobność gospodarstw domowych w Polsce. Raport z badań 2016 r.. Narodowy Bank Polski, Warszawa 2017

\section{Summary}

Objective - To determine the preferences of Polish representatives included in the group of those aged $65+$ in using the basic types of products on the banking market.

Test method - Survey conducted on a group of 569 respondents belonging to the generation of those aged 65+; made with the use of a questionnaire from March to May 2018. Preceded by a pilot study carried out in January 2018.

Result - The behavior of Poles belonging to the generation of those aged $65+$ on the banking services market was defined. The level of interest in banking products and the level of activity in using these products was estimated, as well as the preferred ways to implement banking services. An analysis of the banking products portfolio of this customer segment was made.

Originality / Value - The results of the research are an extension of the state of knowledge about the behavior of clients belonging to those aged $65+$ on the Polish banking services market.

Keywords: banking services, banking, generation $65+$

JEL Codes: G21, J14.

Informacja o autorze:

Mirosław Sołtysiak, dr inż.

Politechnika Rzeszowska

al. Powstańców Warszawy 8, Rzeszów, Polska

e-mail: miroslaw@prz.edu.pl

ORCID: 0000-0003-3366-1537 